\title{
POVEZIVANJE DIGITALNIH PODATAKA \\ IZ DISTRIBUIRANIH IZVORA NA PRIMJERU IZGRADNJE VIRTUALNE IZLOŽBE CRTEŽI HUGA CONRADA VON HÖTZENDORFA
}

\author{
LINKAGE OF DIGITAL DATA FROM DISTRIBUTED SOURCES \\ ON THE EXAMPLE OF A VIRTUAL EXHIBITION OF THE \\ DRAWINGS BY HUGO CONRAD VON HÖTZENDORF
}

\author{
Vesna Vlašić Jurić \\ Nacionalna i sveučilišna knjižnica u Zagrebu \\ vvlasic@nsk.hr \\ Marija Perkec \\ samostalna istraživačica \\ marija.perkec@gmail.com
}

UDK / UDC [005.922.52:004.932]:025.3

Stručni rad / Professional paper

Primljeno / Received: 30. 3. 2018.

Prihvaćeno / Accepted: 12. 6. 2018.

\section{Sažetak:}

Cilj. Virtualne izložbe predstavljaju važan oblik okupljanja i predstavljanja digitalne kulturne baštine. Cilj je rada predstaviti značajke postupka povezivanja digitalnih podataka iz distribuiranih izvora na primjeru digitalizacije građe, fizičke izložbe, digitalne tematske zbirke građe Huga Conrada von Hötzendorfa i virtualne izložbe Crteži Huga Conrada von Hötzendorfa. Povezivanje digitalnih podataka iz distribuiranih izvora u obliku virtualne izložbe trebalo bi omogućiti interpretaciju i kontekstualizaciju crteža iz fonda Zbirke s drugim vanjskim izvorima podataka.

Pristup/metodologija/dizajn. U radu se opisuju faze izrade izložbe od obrade građe, pripreme i izrade fizičke izložbe, digitalizacije i izrade digitalne zbirke do izrade

Vjesnik bibliotekara Hrvatske 61, 1(2018), 555-572

ISSN 0507-1925

(C) VBH 2018. 
virtualne izložbe. U radu se prikazuju prednosti korištenja formata MARC 21 zbog standardiziranosti prikaza, korisničke dostupnosti bibliografskog zapisa na mrežnom katalogu, ali i mogućnosti obogaćivanja zapisa povratnom poveznicom na digitalni repozitorij i virtualnu izložbu te prepreke u integraciji podataka različitih sustava (Aleph, Indigo i WordPress).

Rezultati. Rezultat je izrada virtualne izložbe koja omogućuje jedinstvenu interpretaciju koju je zbog kompleksnosti teme, interdisciplinarnog pristupa te disperzije građe bilo nemoguće realizirati u okviru fizičke izložbe. Izradi virtualne izložbe prethodila je izrada digitalne zbirke u sustavu Digitalne zbirke Nacionalne i sveučilišne knjižnice u Zagrebu gdje su podaci iz sustava Aleph preneseni u sustav Indigo zahvaljujući interoperabilnosti tih sustava. Inovativan način prezentiranja takve vrste građe može biti primjer i daljini poticaj za širenje informacija i znanja, kao i digitalno predstavljanje bogate kulturne baštine širem krugu različitih korisnika.

Originalnost/vrijednost. Vrijednost je ove virtualne izložbe u kvaliteti platforme WordPress koja omogućuje okupljanje i kreativno predstavljanje građe iz različitih izvora te vizualizaciju podataka. To je prva virtualna izložba izrađena za likovnu građu Grafičke zbirke Nacionalne i sveučilišne knjižnice u Zagrebu, koja je donijela razvojni pomak unosom oznaka (tagova).

Ključne riječi: crteži , digitalni podatci, H. C. von Hötzendorf, virtualna izložba

\begin{abstract}
Purpose. Virtual exhibitions are an important mode of assembling and presenting digitized cultural heritage. The aim of this paper is to present the process of integration of digital data from distributed sources on the example of a virtual exhibition of Drawings by Hugo Conrad von Hötzendorf. The integration of the content from distributed sources should provide a unique interpretation and contextualization of the drawings of Hugo Conrad von Hötzendorf presented from the Print Collection of the National and University Library in Zagreb and other external data sources.
\end{abstract}

Approach. The paper describes development phases that included cataloguing the works of art, preparing and setting up the exhibition in a physical space, digitizing the works and the development of the digital collection and digital exhibition. The application of the MARC 21 format has shown advantages in standardization and reuse of bibliographic data, as well as in the possibility of enrichment of the bibliographic record with a virtual exhibition link and National and University Library's Digital Database Repository link as well as obstacles occurring with the integration of data into different systems (Aleph, Indigo and WordPress).

Findings. The result is a virtual exhibition that provides a unique interpretation which was impossible to realize in real exhibition space due to its complexity, the interdisciplinary approach and dispersion of the material. The virtual exhibition process was preceded 
by the creation of the digital collection in a digital repository by transferring data from Aleph into the Indigo system which was possible because of the interoperability of those systems. This innovative way of presenting such material can serve as a model and enticement for future projects dealing with the digital presentation of cultural heritage.

Originality/Value. The value of this virtual exhibition is the quality of the WordPress platform's possibilities for assembly and creative presentation of material from different sources and data visualisation. The first virtual exhibition created for the art works in the Library's holdings has made a shift in development with the introduction of tags.

Keywords: drawings, H. C. von Hötzendorf, linkage of digital data, virtual exhibition

\section{Uvod}

Grafička zbirka Nacionalne i sveučilišne knjižnice u Zagrebu osnovana je 1919. godine kao zaseban odjel u sklopu Sveučilišne knjižnice. Naime u spremištima knjižnice nalazila se veća količina neknjižne građe likovnog karaktera koja je zahtijevala drukčiji pristup u procesu knjižničnog poslovanja u odnosu na knjižnu građu. Povjereništvo za bogoštovlje i nastavu već krajem 1918. godine razmatra osnivanje takva odjela te je 28. listopada održana sjednica Povjerenstva s ciljem realizacije te ideje, a sredinom sljedeće godine dr. Artur Schneider imenovan je prvim voditeljem Grafičke zbirke. ${ }^{1}$ Inicijalni fond Zbirke bila je već spomenuta likovna građa nađena u spremištma knjižnice. Uglavnom se radilo o pojedinačnim grafičkim listovima i crtežima, kao i donacijama nekih od vodećih hrvatskih umjetnika: Ljube Babića, Mencija Clementa Crnčića i Tomislava Krizmana. Dr. Artur Schneider bio je svjestan važnosti promišljene i kvalitetne izgradnje fonda Zbirke. Listajući inventarnu knjigu crteža može se uočiti da je prvo umjetničko djelo kupljeno za fond Zbirke akvarel pod nazivom „Perivoj“ autora Huga Conrada von Hötzendorfa. Dakle 1920. godine dr. Artur Schneider kupuje od Isidora Kršnjavog 31 crtež već spomenutog autora, odnosno radilo se o 21 crtežu izrađenom olovkom te 10 akvarela (slike 1 i 2 ).

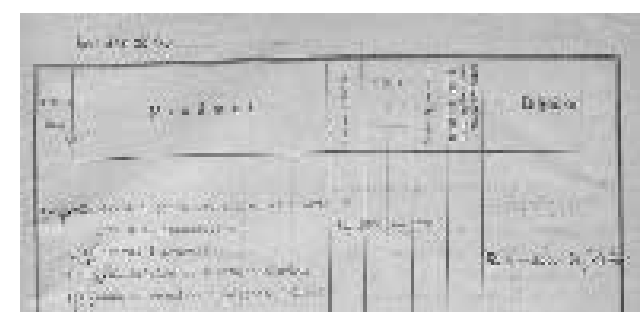

Slika 1. Inventarna knjiga GZ NSK

1 Odluka o imenovanju, br. spisa: 16.349, 1919. Arhiv NSK. 


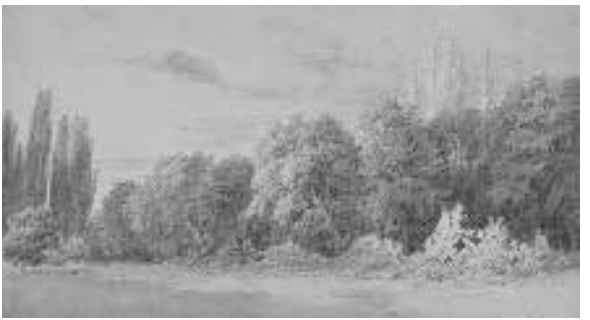

Slika 2. H. C. von Hötzendorf, Perivoj, 1846. (GZAH 171 hoe 1)

Ta prva akvizicija dala je ideju za organizaciju izložbe u čitaonici Grafičke zbirke. Istražujući materijale o životu i umjetničkom stvaralaštvu Huga Conrada von Hötzendorfa, ideja o izložbi pokazala se kao dobra odluka jer je razloga za izložbu bilo više od prvotne zanimljivosti vezane uz nabavu crteža. Naime dulje nije bilo izložbe Hötzendorfovih radova u Hrvatskoj, a kao jedna od mogućih godina autorova rođenja u postojećoj literaturi spominje se 1807 . godina, pa bi se izložbom u Grafičkoj zbirci obilježila i obljetnica umjetnikova rođenja. ${ }^{2}$ Činjenica da postoji više mogućih godina rođenja ukazuje na nedostatak pisanih podataka o biografiji Huga Conrada von Hötzendorfa, pa tako crteži iz fonda Grafičke zbirke nastali u razdoblju nakon povratka sa školovanja u Beču, osim o iznimnom likovnom i umjetničkom senzibilitetu, svjedoče i o određenom razdoblju umjetnikova života kao jedini pouzdani izvori i dokumenti jer se na crtežima uz naslov prikazanog mjesta nalazi i godina njihova nastanka. ${ }^{3}$ Ti crteži iz fonda Zbirke po motivima bi mogli biti razvrstani u dvije skupine. U prvoj su skupini crteži manjih i većih formata na kojima se nalazi više manjih skica ljudi, konja i drveća. Uz tu seriju crteža u fondu Zbirke nalaze se i dva crteža velikolisnih biljaka: „Akantus“"i „Bundeve“. Drugu skupinu čine crteži s motivima pejzaža. Uglavnom su to crteži slavonskih predjela, ali i oni koji prikazuju neke druge dijelove Hrvatske, Slovenije i Austrije kroz koje je Hötzendorf putovao. Romantičarske odlike i kvalitete Hötzendorfova stila očituju se i u ovoj seriji crteža. ${ }^{4}$ Nesporno je da je Hugo Conrad von Hötzendorf jedan od najznačajnijih slikara koji su se pojavili na osječkoj umjetničkoj sceni 19. stoljeća. Iako u svom bogatom slikarskom opusu izrađuje i druge motive, pejzaž ostaje neiscrpan izvor njegova likovnog nadahnuća te se on opravdano smatra jednim od najznačajnijih slikara pejzaža tog razdoblja u Hrvatskoj. Bio je i vrstan likovni pedagog te je kao dugogodišnji voditelj Osječke crtačke škole utjecao na likovni razvoj nekolicine značajnih hrvatskih slikara i teoretičara kao što su A. Waldinger i Isidor Kršnjavi. ${ }^{5}$

I. Mažuran tvrdi da se rodio u Brnu 1798. godine, I. Kršnjavi spominje Brno 1804. godine, a J. Bösendorfer kao mjesto rođenja navodi Dardu 1807. godine. Podaci preuzeti iz Švajcer, O. Hötzendorf, Zagreb: Centar za povijesne znanosti, Odjel za povijest umjetnosti, 1982. Str. 30.

3 Vlašić Jurić, V. Crteži Huga Conrada von Hötzendorfa u Grafičkoj zbirci Nacionalne i sveučilišne knjižnice u Zagrebu: katalog izložbe. Zagreb: Nacionalna i sveučilišna knjižnica u Zagrebu, 2017. Str. 7.

4 Isto, str. 7.

5 Usp. Conrad von Hötzendorf, Hugo. // Hrvatski biografski leksikon. [citirano: 2018-05-10]. Dostupno na: http://hbl.lzmk.hr/clanak.aspx?id=3651. 


\section{Katalogizacija i digitalizacija crteža}

Prije izložbe crteži su katalogizirani u knjižnično-informacijskom sustavu NSK-a i digitalizirani. Prethodno su, po ulasku u fond Zbirke, upisani u dnevnik / inventarnu knjigu te je za svaki primjerak građe izrađen kataložni listić koji sadrži podatke o autoru, naslovu, tehnici, načinu nabave, smještaju, signaturi, opisu, dimenzijama te načinu nabave građe. U strojnoj obradi građe Grafičke zbirke NSK primijenjuje se ISBD Međunarodni standardni bibliografski opis i format MARC $21^{6}$, a podaci se unose u sustav Aleph. Likovna građa predstavlja izvor mnoštva različitih informacija koje treba opisati na odgovarajući način te ih tako učiniti dostupnijima različitim tipovima korisnika. Dakle prije katalogizacije treba iščitati formalne i sadržajne informacije likovne građe, u ovom slučaju Hötzendorfovih crteža, što uključuje dimenziju, tehnike te druga bitna fizička obilježja, a zatim i godinu i mjesto nastanka. Uz te formalne informacije potrebno je obraditi i informacije o sadržaju djela, koje mogu uključivati različite pojmove. ${ }^{7}$ Kako se na većini crteža spomenutog autora koji su u fondu Zbirke nalazi naziv mjesta, godina nastanka te potpis autora, nije bilo potrebno istraživati te podatke. Bibliografski zapis crteža sadrži kodirane podatke za dvodimenzionalnu grafiku, podatke o autorstvu (Polja odrednica glavnih kataložnih jedinica - polje 100 Osobno ime, obiteljsko ime), naslov (Polja naslova i ostala srodna polja - polje 245 Stvarni naslov i podaci o odgovornosti) te vrijeme nastanka crteža (Polja izdanja, izdavanja itd. - polje 260 Izdavanje, raspačavanje). Podatak o vrsti građe, tehnici te dimenziji unosi se u Polja materijalnog opisa (u ovom slučaju polje 300 Materijalni opis). Polja napomena $(500,520,533,583)$ sadrže podatke o potpisu autora, naslovu i godini koji se nalaze na izvorniku, podatke o publikaciji u kojoj je crtež reproduciran, kratak opis sadržaja, zatim podatke o vremenu kada je crtež digitaliziran (mjesec i godina) te, naposljetku, podatak o tome kada je crtež pregledan, restauriran i opremljen (godina, mjesec i datum). Polje 651 (Sporedna kataložna jedinica za predmet - Geografsko ime), kao i polje 653 (Pojam u kazalu - slobodno oblikovan), spadaju u Polja predmetnih odrednica. Polje 651, drugi indikator 7 , koristi se kod katalogizacije crteža koji moraju dobiti geografsku odrednicu ${ }^{8}$ te se

${ }^{6}$ ISBD: međunarodni standardni bibliografski opis / preporučila Skupina za pregled ISBD-a ; odobrio stalni odbor IFLA-ine Sekcije za katalogizaciju ; [s engleskog prevela i predgovor napisala Ana Barbarić]. Objedinjeno izd. Zagreb : Hrvatsko knjižničarsko društvo, 2014. Prije se koristio ISBD(NBM) : međunarodni standardni bibliografski opis neknjižne građe / [s engleskoga prevela, hrvatske primjere odabrala i izradila Vedrana Juričić]. Zagreb : Hrvatsko bibliotekarsko društvo, 1993.

7 Vlašić Jurić,V.; T.Ilić Olujić. Važnost odrednice za vrstu i fizičko obilježje pri sadržajnoj obradi i analizi likovnih djela: na primjeru likovne građe iz Grafičke zbirke NSK u Zagrebu. // Vjesnik bibliotekara Hrvatske 57, 1-3(2014), 379-380. Dostupno i na: https://www.hkdrustvo.hr/vjesnik-bibliotekara-hrvatske/index.php/vbh/article/view/128/123 [citirano: 2018-05-10].

8 Kao primjer navodi se crtež pod naslovom „In der Wochein“, gdje je nakon provjere utvrđeno da je Wochein geografsko ime na njemačkom za Bohinj te se Bohinj upisuje u potpolje \$a, dok se u potpolje $\$ 2$ upisuje izvor - nskps. 
tada preuzima normativni zapis izrađen po uputama za izradu geografskih imena u normativnoj bazi NSK-a ${ }^{9}$, dok se u polje 653 , indikator 0 , unosi podatak o tehnici izrade crteža. ${ }^{10}$ Kod katalogizacije crteža dalje se koriste polja 852 (upisuje se prvi indikator 4 i potpolje \$y - Kontrolni broj smještaja na polici) te polje 876 (\$e za unos podataka o izvoru nabave i \$a za interni broj primjerka). Zapis digitalizirane građe čija se digitalna preslika nalazi u sustavu Digitalne zbirke NSK sadrži i polje 856 za elektroničku lokaciju i pristup. Na primjerima bibliografskih zapisa Hötzendorfovih crteža to znači povezivanje na digitalnu presliku u sustav već spomenute Digitalne zbirke NSK i na internetski portal virtualna.nsk.hr, odnosno virtualnu izložbu Crteži Huga Conrada von Hötzendorfa. Na taj način korisnik pretražujući mrežni katalog NSK-a po autoru, naslovu, riječima iz naslova, predmetu i ključnim riječima, a uz tekstualni zapis, vidi i digitalnu presliku određenog crteža, što je najbolji način prezentiranja vizualne građe ${ }^{11}$ (slika 3).

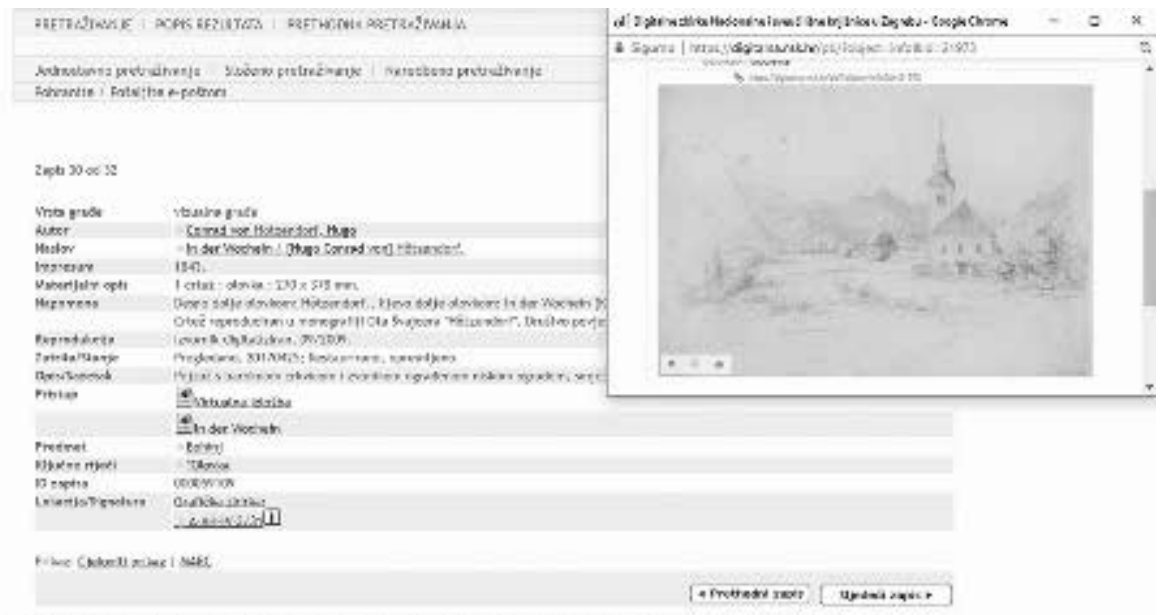

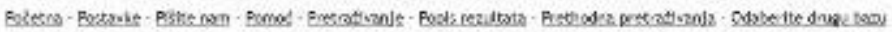

Slika 3. Primjer zapisa u katalogu NSK-a s poveznicom na digitalnu presliku

\footnotetext{
9 Miletić Drder, M.; L. Jurić Vukadin; M. Vujić; M. Vučković Pepeonik. Geografska imena [Elektronička građa]: upute za izradu i klasificiranje predmetnih preglednih zapisa u formatu MARC 21. Zagreb: Nacionalna i sveučilišna knjižnica u Zagrebu, 2012. Dostupno i na: http://www.nsk.hr/ wp-content/uploads/2012/04/geografske-predmetne-odrednice.pdf [citirano: 2018-05-10].

10 Kod već navedenog crteža tehnika se upisuje u potpolje \$a Olovka.

11 Druge muzejske jedinice u Hrvatskoj koje u svom fondu posjeduju likovnu građu nastalu na papiru koriste sustave i programe kao što je npr. $\mathrm{M}++$, koji građu obrađuju po sličnim parametrima, ali oni nisu korisnički dostupni. Više o programu na M++: priručnik za rad. Link 2, 2004. [citirano:2018-06-06]. Dostupno na: http://mdc.hr/files/pdf/koordinacija-mreze-muzeja/prirucnik5. pdf.
} 


\section{Virtualna izložba Crteži Huga Conrada von Hötzendorfa}

Skeniranjem građa dobiva digitalni oblik koji predstavlja završni korak u procesu inventarizacije i katalogizacije građe u svrhu očuvanja kulture baštine i boljeg pristupa. No uz očuvanje, zadatak je kulturnih ustanova i interpretacija te vrednovanje baštine u svrhu širenja i stvaranja novih znanja o građi koju pohranjuju. ${ }^{12}$ Stoga u procesu koji se naziva digitalnom tranzicijom kulturne baštine ${ }^{13}$ digitalizacija građe i katalogizacija koja joj prethodi postaju temelj procesa koji se može označiti digitalnom interpretacijom i valorizacijom građe, a to je izrada virtualnih izložbi.

Prije nego što se na primjeru izgradnje virtualne izložbe Crteži Huga Conrada von Hötzendorfa prikažu značajke povezivanja digitalnih podataka s ciljem jedinstvene interpretacije, valja razmotriti dvije važne distinkcije - onu između pojmova virtualna izložba i digitalizirana građa te onu između pojmova virtualna izložba i fizička izložba.

Prvom paru, virtualna izložba i digitalizirana građa, zajednički je mrežni prostor, no dok digitalizirana građa predstavlja elektronički format građe u repozitoriju, virtualna izložba predstavlja širu značenjsku cjelinu zbog mogućnosti povezivanja digitalizirane građe u priču. ${ }^{14} \mathrm{Za}$ razliku od digitalnih zbirki, gdje su korisniku dostupni zapisi s metapodacima i digitalnom reprezentacijom građe koji su tek povezani u cjelinu zajedničkog autorstva H. C. von Hötzendorfa (slika 4), kod virtualnih izložbi naglašava se koncept priče te se ti podaci interpretiraju i vrednuju u određenom digitalno kreiranom kontekstu - primjerice važnost Hötzendorfovih crteža kao izvora podataka o njegovu životu ili interdisciplinarni pristup njegovim crtežima kao vrijednim konzervatorskim dokumentima.

\footnotetext{
12 Handbook on virtual exhibitions and virtual performances: version 1.0. Ministro per i beni e le attivita culturali; INDICAT, 2012. Str. 11. [citirano: 2018-03-15]. Dostupno na: http://www.digitalmeetsculture.net/wp-content/uploads/2013/01/Handbook_on_Virtual_Exhibitions_and_Virtual_Performaces.pdf.

13 Isto, str. 7.

14 Digitalizirana građa Grafičke zbirke Nacionalne i sveučilišne knjižnice u Zagrebu, uključujući i digitalnu zbirku crteža H. C. von Hötzendorfa, dostupna je na repozitoriju Digitalne zbirke NSK https://digitalna.nsk.hr/pb/.
} 


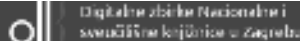

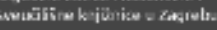
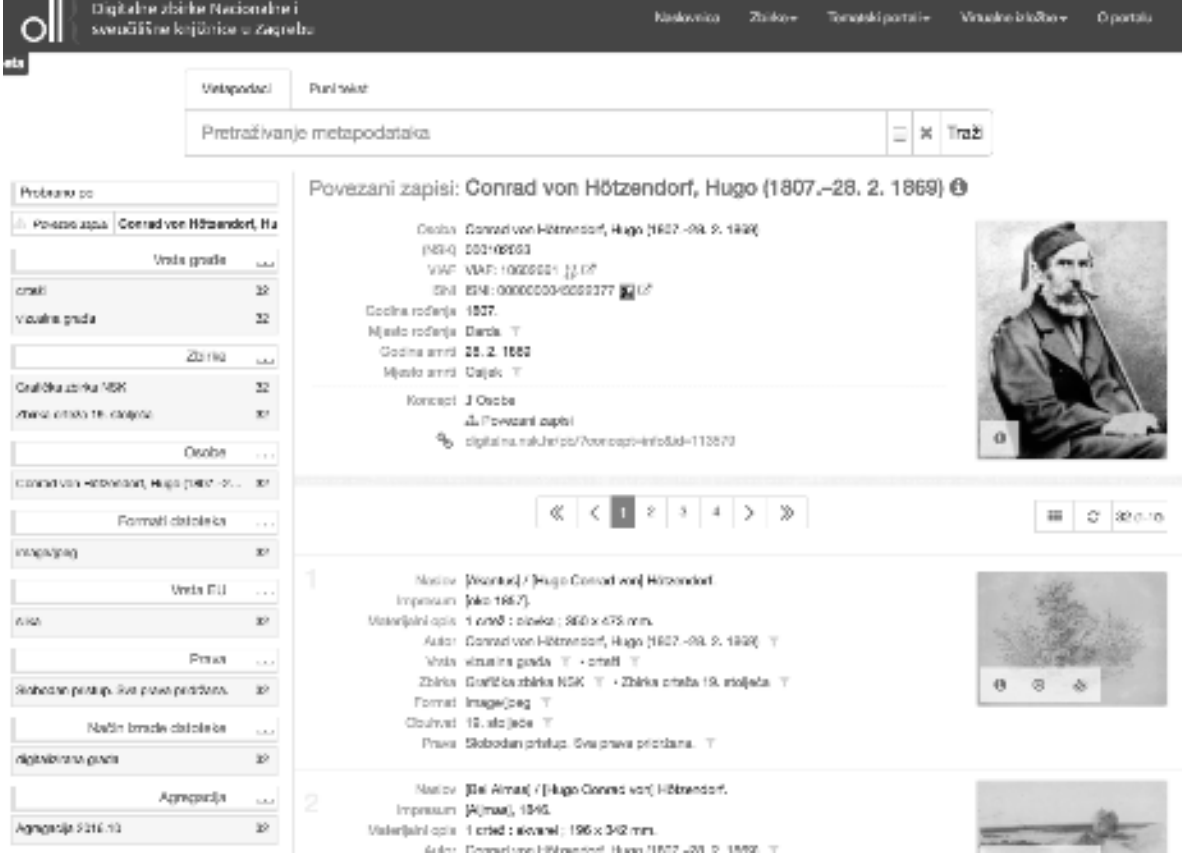

Slika 4. Digitalna zbirka crteža H. C. von Hötzendorfa na digitalnom repozitoriju Digitalne zbirke NSK

Druga distinkcija ima temelj u odnosu virtualno/fizičko, no riječ izložba koja je zajednička objema sintagmama implicira da je riječ o mediju kojim se prenose određene informacije i znanja. Virtualne izložbe tako mogu biti inicirane nekim stvarnim događajem - fizičkom izložbom, kao što i jest u slučaju izložbe Crteži Huga Conrada von Hötzendorfa, no zbog različitog prostora, a time i načina prezentiranja priče, nužno ih je promatrati kao dva zasebna i autonomna događaja, iako u odnosu na izložbe u tradicionalnom smislu te riječi virtualne izložbe predstavljaju svojevrsnu dopunu ${ }^{15}$, posebno u pogledu kontekstualizacije, jer je kod fizičkih izložbi, kada je riječ o kompleksnoj temi, teško prezentirati različite kontekste i namjeru njihova uvrštavanja budući da je redovito riječ o prezentaciji djela i popratnom tekstu u katalogu izložbe. Virtualne izložbe kao multimedijski hipertekst omogućuju simultanu percepciju različitih relacijskih polja - slika, tekst, video i slično, pa time otvaraju mogućnost jedinstvene interpretacije i vrednovanja građe. ${ }^{16} \mathrm{U}$ tom kontekstu važno je istaknuti još jednu odliku virtualnih izložbi u odnosu na fizičke izložbe, a to je dostupnost, jer građa prezentirana kroz prostor weba postaje dostupnija široj zajednici korisnika.

15 Handbook. Nav. dj. Str.17.

16 Isto, str. 26. 
Izrada virtualne izložbe Crteži Huga Conrada von Hötzendorfa bila je motivirana vrijednim crtežima koji su pohranjeni u fondu Grafičke zbirke. ${ }^{17} \mathrm{Cilj}$ joj je bio donijeti i prezentirati jedinstvenu interpretaciju koju je zbog kompleksnosti teme, interdisciplinarnog pristupa koji zahtijeva te disperzije građe bilo nemoguće realizirati u okviru fizičkih izložbi. Upravo je takav pristup temi u okviru izrade virtualne izložbe omogućio proces povezivanja digitalnih podataka.

Realizacija virtualne izložbe Crteži Huga Conrada von Hötzendorfa može se prikazati kroz sljedeće faze:

- prikupljanje izvora informacija za tekstove te digitalizirane građe Nacionalne i sveučilišne knjižnice u Zagrebu - crteži, karte, razglednice i grafike - i drugih baza podataka: Hrčak i DiZbi HAZU

- izrada konceptualne mape teme s relacijskim poljima - stvaranje idejnog nacrta okupljanja digitalnih podataka

- izgradnja arhitekture virtualne izložbe

- objavljivanje i predstavljanje virtualne izložbe te obogaćivanje bibliografskog zapisa povratnom poveznicom na virtualnu izložbu.

\subsection{Konceptualna mapa teme s relacijskim poljima - struktura virtu- alne izložbe}

Izrada konceptualne mape teme prvi je korak u procesu izgradnje virtualne izložbe. ${ }^{18} \mathrm{U}$ odnosu na cijeli proces izrade, konceptualna mapa može se označiti idejnim nacrtom virtualne izložbe. Konceptualna mapa sastoji se od relacijskih polja na temelju kojih se gradi priča koja se želi komunicirati, a u okviru kojih se naznačuje i povezivanje digitalnih podataka. Organizaciju konceptualne mape, dakako, uvjetuje tema i pojedini segmenti koji se žele prezentirati u formi priče. Relacijska polja u okviru konceptualne mape mogu pratiti logiku dedukcije, pri čemu se jedno polje organizira kao temeljno relacijsko, a potom se druga polja

17 Virtualna izložba dostupna je na Crteži Huga Conrada von Hötzendorfa. [citirano:2018-06-06]. Dostupno na: http://virtualna.nsk.hr/hotzendorf/.

Ideja o izradi virtualne izložbe nastala je u sklopu seminara Virtualne izložbe digitalizirane građe koji je održan 29. svibnja 2017. godine u Nacionalnoj i sveučilišnoj knjižnici u Zagrebu. Na pomoći u realizaciji izložbe zahvaljujemo: Odjelu zaštite i pohrane NSK na opremanju, restauraciji građe i digitalizaciji građe, Sonji Hrelji, Darku Čižmeku (NSK) i Ivanu Rothu (MLU Osijek) na fotografijama koje su korištene u izradi virtualne izložbe, Maji Karić (GZ NSK) i Miri Miletić-Drder (KZ NSK) na pripremi, obradi preslika i metapodacima na Digitalnim zbirkama NSK, Maji Karić (GZ NSK) na dizajnu logotipa te suurednicama izložbe Tamari Ilić-Olujić, Sofiji Klarin Zadravec i Karolini Holub (NSK).

18 Takav princip izrade virtualne izložbe, koji započinje izradom konceptualne mape teme s relacijskim poljima i gdje se spominje navedeni termin relacijskih polja, preuzet je iz Dumitrescu, G.; C. Lepadatu.; C. Ciurea, Creating virtual exhibitions for educational and cultural development. // Informatica Economică 18, 1(2014), str. 107. [citirano: 2018-05-02]. Dostupno na: http://revistaie.ase.ro/content/69/09\%20-\%20Dumitrescu,\%20Lepadatu,\%20Ciurea.pdf. 
unutar njega organiziraju kao nadređeni tematski okviri i potpolja koja će slijediti zadanu logiku od općeg prema pojedinačnom. Prilikom izrade mape važno je naznačiti i različite ili moguće varijante organizacije jer se ona kasnije prenosi u računalnu izradu koja će prvenstveno zahtijevati određene prilagodbe mogućnostima softvera u kojem se izrađuje virtualna izložba.

Budući da je riječ o prezentaciji Hötzendorfovih crteža pohranjenih u fondu Grafičke zbirke Nacionalne i sveučilišne knjižnice u Zagrebu, upravo su sami crteži bili primarna stavka organizacije relacijske mape. Uspostavljena je prezentacija crteža kroz život i djelo autora, o čemu danas svjedoči malo podataka, a upravo su se zahvaljujući crtežima popunjavali i utvrđivali biografski podaci. Na životopis umjetnika nastavlja se priča o crtežima u kontekstu Grafičke zbirke Nacionalne i sveučilišne knjižnice u Zagrebu. Konceptualna mapa stoga za temeljnu relaciju ima polje nazvano „Crteži“, koje se potom dijeli na biografiju umjetnika i Grafičku zbirku, polja koja su konstruirana kao nadređeni tematski okvir konstrukciji priče i povezivanju digitalnih podataka (slika 5).

Polje „Životopis“ razgranato je na nekoliko podtematskih/relacijskih polja. „Biografske crtice“ sadrže osnovne i poznate podatke o Hötzendorfovu životu: godina/e i mjesto/a rođenja te smrti, informacije o studiju te pedagoškom djelovanju (crtačke škole, nagrade). Unutar tog tematskog okvira naznačeno je okupljanje digitalizirane građe Grafičke zbirke - razglednica i grafika, s ciljem vizualne prezentacije tih faktografskih podataka. „Putovanja“ i „Motivi“ predstavljaju dva relacijska polja koja se međusobno preklapaju jer je većina crteža nastala upravo tijekom putovanja te su stoga izdvojeni kao zaseban biografski segment. Uz pregled zastupljenih motiva, šira kontekstualizacija crteža predviđena je povezivanjem digitaliziranih članaka o konzervatorskoj i dokumentarnoj važnosti te o vremenskom pozicioniranju crteža u razdoblje romantizma. Uz digitalizirane članke predviđeno je i okupljanje digitaliziranih razglednica i karata u svrhu usporedbe s crtežima te prezentacije prostora putovanja. Sljedeće relacijsko polje predstavlja Hötzendorfovo pedagoško djelovanje u risarskim/crtačkim školama koje se proširuje digitaliziranim člankom o osječkoj, ali i drugim školama te objašnjava njihovo osnivanje i popularizaciju tijekom 19. stoljeća. Polje „Utjecaj“ konstruirano je kao zasebno potpolje „Crtačkih škola“ budući da su Hötzendorfovi učenici bili Adolf Waldinger i Isidor Kršnjavi čiji crteži, nastali za potrebe podučavanja povijesti umjetnosti, pokazuju Hötzendorfov pedagoški utjecaj, a pohranjeni su u fondu Grafičke zbirke Nacionalne i sveučilišne knjižnice u Zagrebu. Uz okupljanje digitaliziranih crteža I. Kršnjavog, spomenuto je polje dodatno prošireno digitaliziranim katalogom izložbe akademskog kipara Vanje Radauša gdje su prvi put predstavljene biste Waldingera i Hötzendorfa koje je izradio, a danas su zajedno postavljene u osječkom Sakuntala parku.

Drugi nadređeni tematski okvir, polje „Grafička zbirka“, obuhvaća inventarizaciju i katalogizaciju crteža kao prvih listova upisanih u dnevnik Zbirke te 
izložbu održanu u listopadu 2017. godine. Polje „Valorizacija“ posebno je izdvojeno jer je zahvaljujući prvom voditelju Grafičke zbirke, dr. Arturu Schneideru, povodom izložbe održane 1934. godine valoriziran čitav Hötzendorfov opus te je stoga u shemi konceptualne mape u okviru tog polja naznačen digitalizirani kata$\log$ spomenute izložbe.

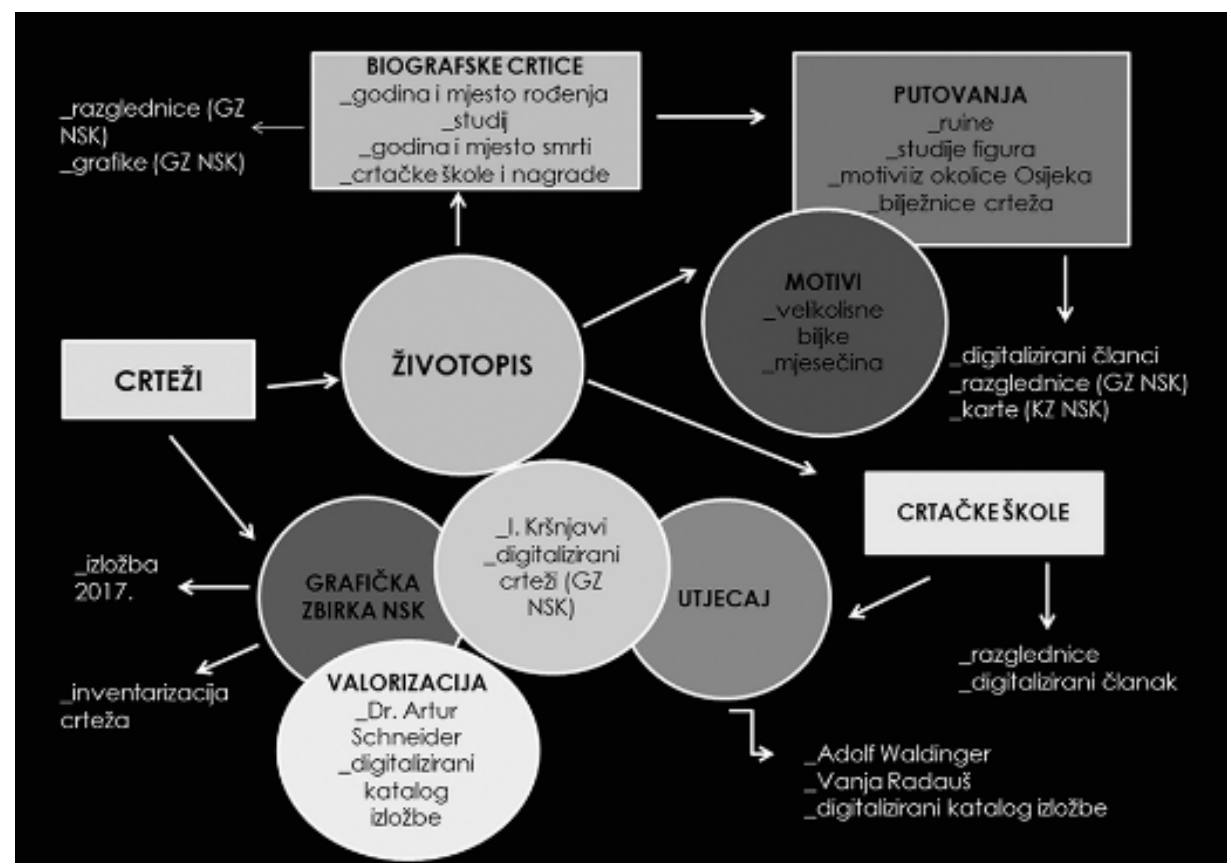

Slika 5. Konceptualna mapa teme

\subsection{Izrada virtualne izloz̆be}

Sljedeći korak izgradnje virtualne izložbe te povezivanja digitalnih podataka predstavlja izrada strukture izložbe i unos sadržaja. Pri realizaciji tog koraka konceptualna mapa teme s relacijskim poljima kao idejni nacrt za arhitekturu virtualne izložbe mora se prilagoditi dvjema pretpostavkama:

- U izgradnji virtualne izložbe važnom postaje figura implicitnog korisnika, gdje se temeljna podjela čini na razini stručne publike i šire javnosti i stoga je važno učiniti priču dostupnom i pristupačnom svim vrstama korisnika te im omogućiti vlastiti itinerarij kroz virtualnu izložbu, zbog čega se arhitektura i način povezivanja digitalnih podataka moraju prilagoditi različitim interesima. 
- Arhitektura virtualne izložbe ovisi o mogućnosti taksonomije unutar programa u kojem se izgrađuje i realizira. U slučaju virtualnih izložbi Nacionalne i sveučilišne knjižnice u Zagrebu WordPress omogućuje dva mobilna oblika organizacije priče - kategorija vremenske lente (horizontalna organizacija priče) i oznake (vertikalna organizacija priče) te izbornik kao statični dio virtualne izložbe.

Vremenska lenta predstavlja primarnu linearnu i grafičko-kronološku prezentaciju i organizaciju digitalizirane građe u priču. Osnovni princip organizacije konceptualne mape i povezivanja digitalizirane građe kroz dva nadređena tematska okvira - životopis i Grafičku zbirku Nacionalne i sveučilišne knjižnice u Zagrebu - prenesen je u izgradnju vremenske lente (slika 6).

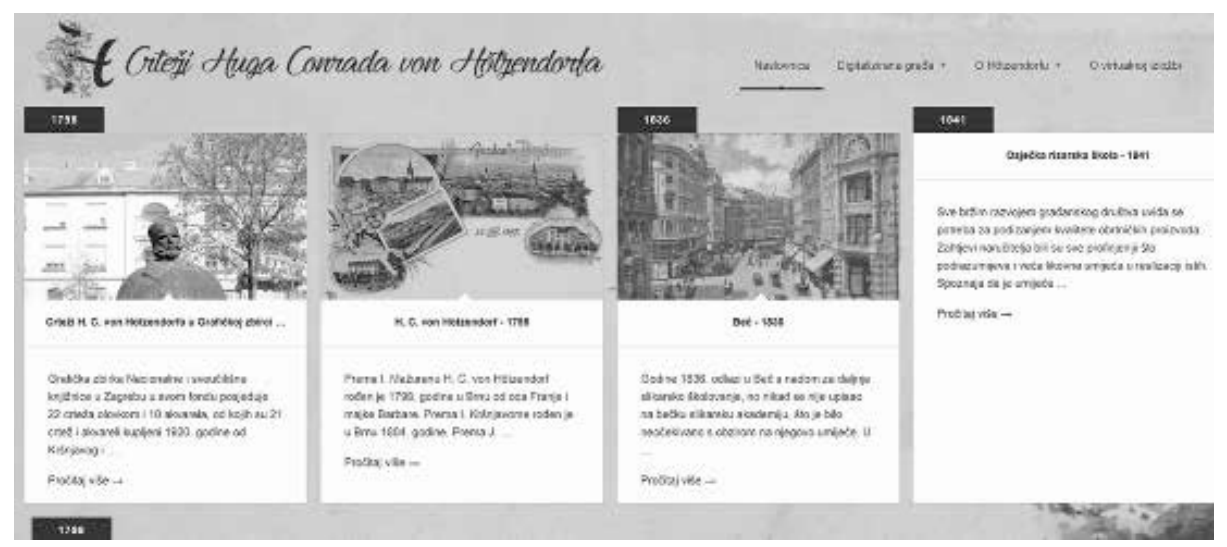

Slika 6. Prikaz objava na vremenskoj lenti

Pojedine objave na lenti tako prate kronologiju Hötzendorfove biografije uz vizualnu prezentaciju i kontekstualizaciju ostvarenu povezivanjem digitalizirane građe - crteža, grafika, karata i razglednica. Objašnjene su sažetim tekstom autora izložbe unutar kojih su okupljeni digitalizirani članci i katalozi izložbi iz drugih baza podataka koji time detaljnije proširuju određeni tematski segment. Za razliku od crteža, grafika, karata i razglednica koji su u virtualnu izložbu uklopljeni reprezentacijom, digitalizirani članci i katalozi izložbi u okviru pojedinih objava uklopljeni su putem poveznica na vanjske izvore, čime korisnik, ovisno o vlastitim interesima i afinitetima, ima mogućnost odabira pristupa tim informacijama. Uz vizualnu reprezentaciju i poveznice na vanjske izvore, treći način povezivanja digitalizirane građe predstavlja interaktivna knjiga koju čine spomenuti crteži Isidora Kršnjavog, a izrađena je u svrhu prezentacije tih listova u njihovu izvornom stanju (slika 7). 


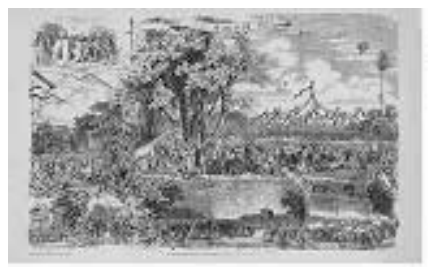

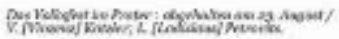
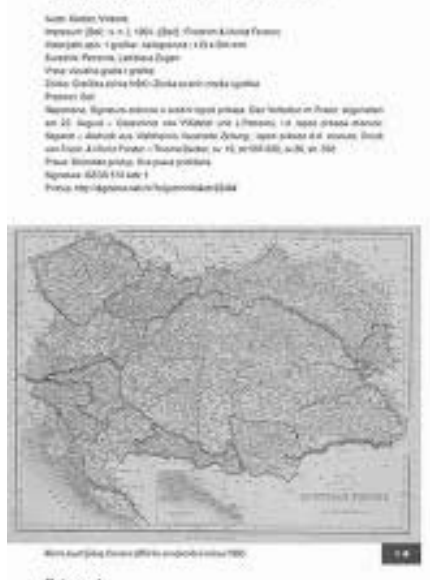

Rlavisa
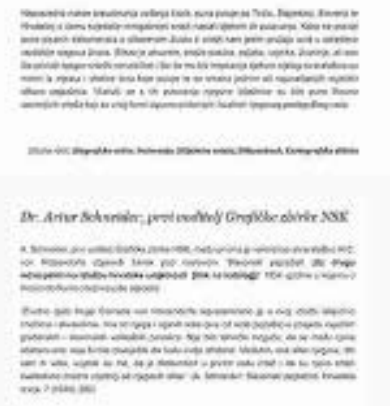

- -20 -
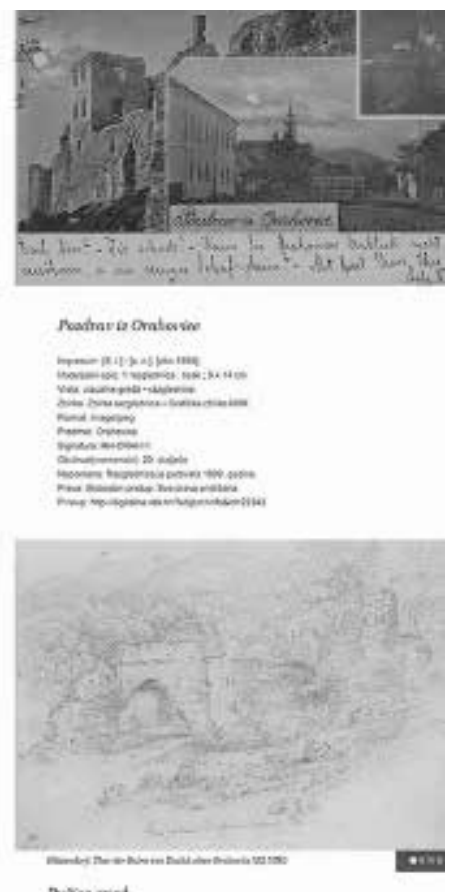

Bumo grist
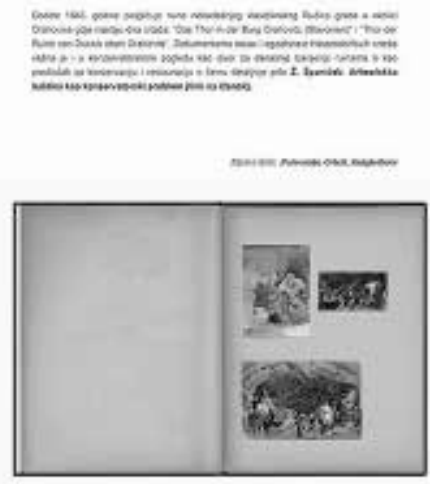

Slika 7. Primjeri povezivanja digitalnih podataka

Vertikalna arhitektura virtualne izložbe kroz oznake uvedena je kako bi se u potpunosti pokrila sva relacijska polja i njihova preklapanja koja su, kao što je vidljivo na shemi konceptualne mape, u slučaju ove teme od izuzetne važnosti za njezinu interpretaciju. Kategoriji vremenske lente u svakoj su od objava pridružene i oznake, tj. ključne riječi, koje se korisniku virtualne izložbe nude kao jedna od mogućnosti razgledavanja i pristupa informacijama (slika 8). Prema ključnim riječima crteži, biografske crtice, putovanja, razglednice, grafike, karte, crtačke 
škole, Grafička zbirka, zanimljivosti i bilježnice crteža objave se organiziraju prema određenoj oznaci, pa korisnik ima mogućnost pregleda određenog tematskog segmenta vezanog u crteže, ali i ostalu digitaliziranu građu ${ }^{19}$ (slika 9).

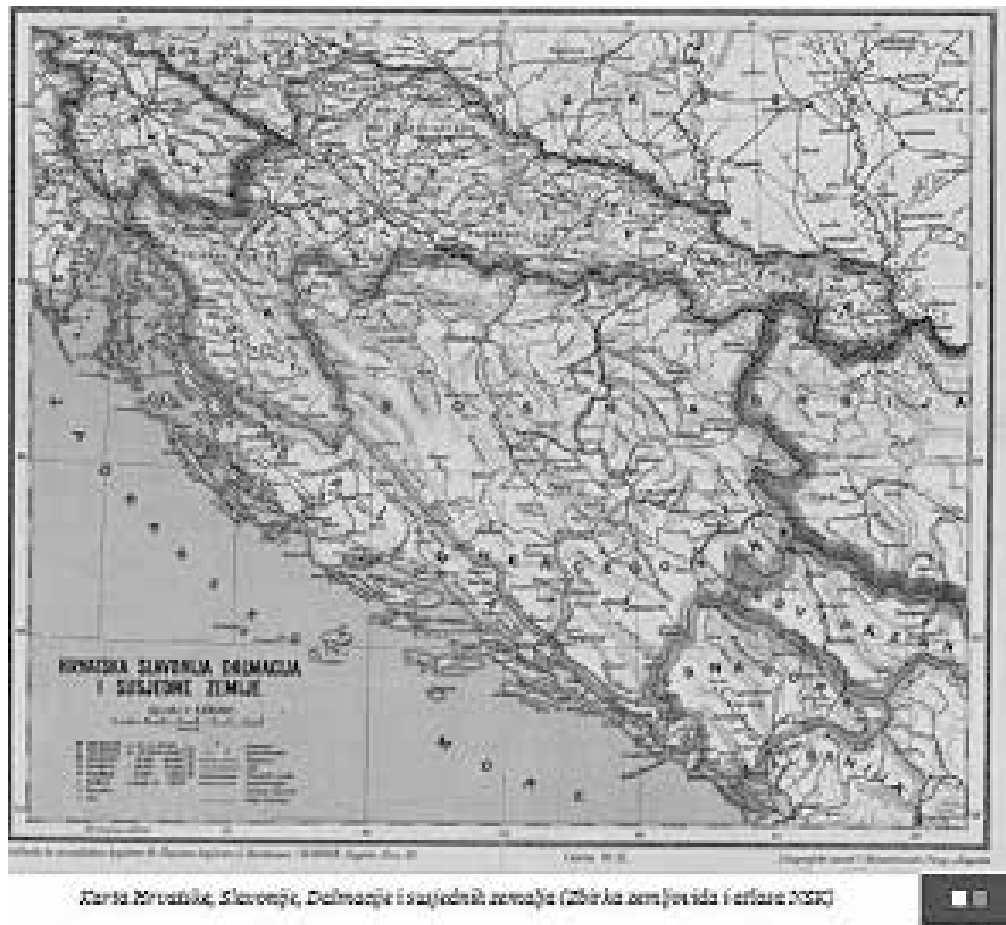

Putovanja

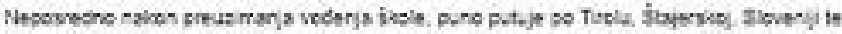

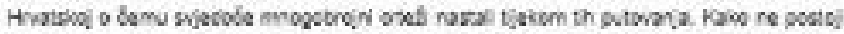

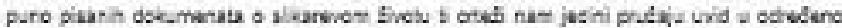

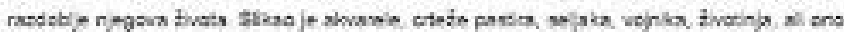

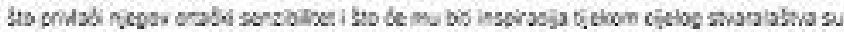

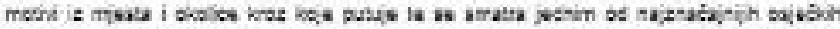

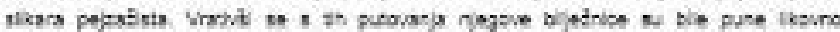

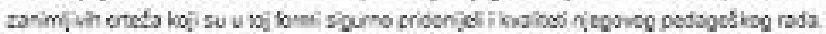

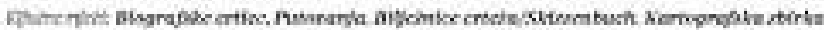

Slika 8. Objava na vremenskoj lenti s pridruženim ključnim riječima

19 Uvođenjem oznaka u izradu virtualne izložbe autorice su imale namjeru uspostaviti inovativan pristup organizaciji arhitekture izložbe te pridonijeti razvoju virtualnih izložbi NSK-a. 


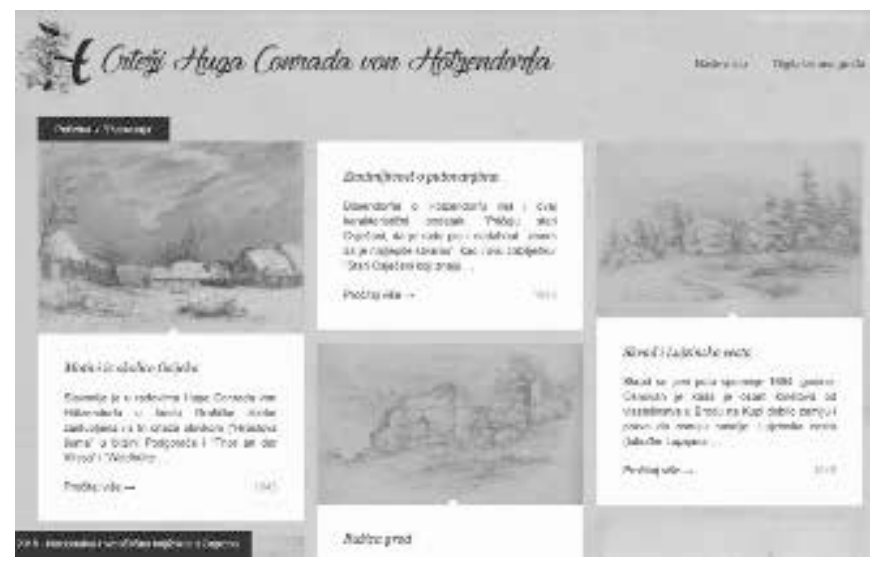

Slika 9. Vertikalna organizacija objava prema ključnim riječima

Statični dio virtualne izložbi čini izbornik u kojem je sadržana građa koja je iz distribuiranih baza podataka okupljena u izložbu - ,Digitalizirana građa“6 $\mathrm{s}$ metapodacima i reprezentacijom te cjelovit i proširen pregled Hötzendorfove biografije u odnosu na vremensku lentu, važnost za hrvatsku povijest umjetnosti, popis literature i izložbi: „O Hötzendorfu“ (slika 10).

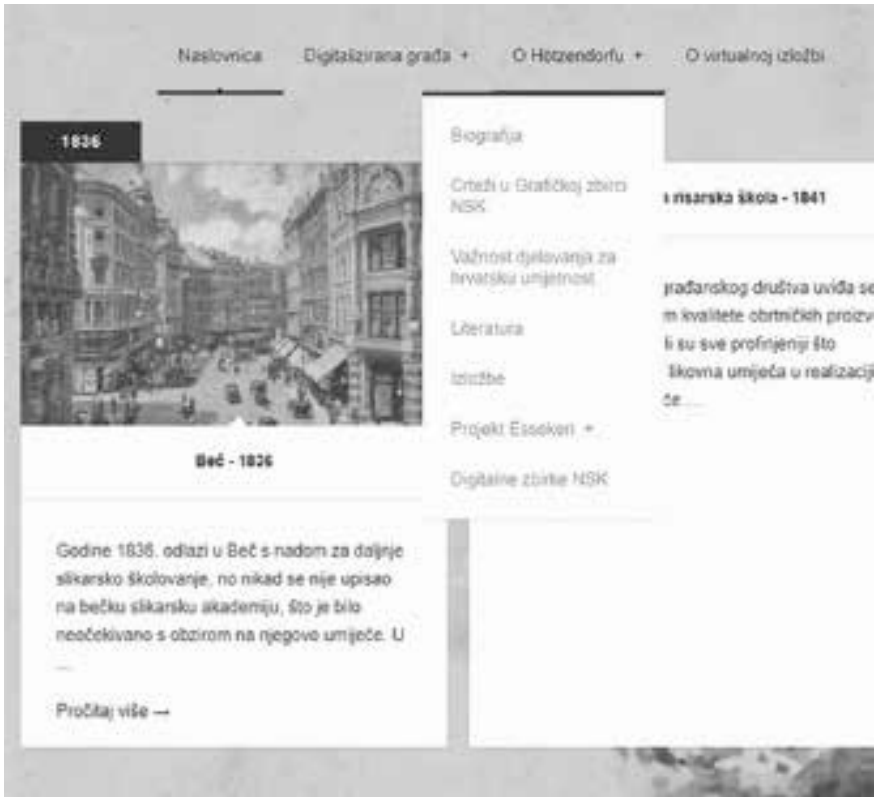

Slika 10. Izgled izbornika 
Takvom organizacijom virtualne izložbe - različitim načinima povezivanja digitalizirane građe, stvaranjem horizontalne i vertikalne taksonomije virtualne izložbe uz statične dijelove u izborniku - željelo se različitim skupinama korisnika ponuditi različite mogućnosti razgledavanja izložbe prema vlastitim interesima i afinitetima. Tako će korisnik zainteresiran za razglednice imati mogućnost usporediti kako je samo nekoliko desetljeća prije nastanaka razglednice taj prizor interpretiran u mediju crteža. Slučaj je to i s arheolozima i konzervatorima, kojima Hötzendorfova putovanja i crteži ruina mogu biti od stručnog i znanstvenog značaja. I povjesničarima umjetnosti ta izložba nudi prvenstveno mogućnost uvida u inventarizirane i katalogizirane crteže u Grafičkoj zbirci Nacionalne i sveučilišne knjižnice, kao i one nastale pod Hötzendorfovim pedagoškim utjecajem. Za korisnike željne zanimljivosti u virtualnu izložbu uključeni su zanimljivi, ali, nažalost, u malom broju zabilježeni trenuci iz umjetnikova života koji su vezani uz nastanak crteža.

Upravo navedeni slijed dostupnih informacija, koje će, neovisno o njegovu interesu i iskustvu virtualne izložbe, korisniku uvijek prenijeti podatak vezan uz Hötzendorfove crteže, potvrđuje važnost postupka povezivanja digitaliziranih podataka iz distribuiranih izvora i njegova značaja za interpretaciju kulturne baštine, a time $i$ istaknuto mjesto virtualnih izložbi u procesu širenja znanja koje za zadatak imaju kulturne ustanove.

\section{Zaključak}

Izgradnja virtualne izložbe Crteži Huga Conrada von Hötzendorfa pokazuje važnost povezivanja različitih digitalnih podataka iz distribuiranih izvora s ciljem jedinstvene interpretacije i kontekstualizacije predstavljenih crteža. Cilj je virtualne izložbe prezentirati jedinstvenu interpretaciju života i rada samog autora te njihovo smještanje u kontekst vremena i prostora kroz povezivanje različitih vrsta digitalne građe iz različitih izvora podataka. U procesu izrade virtualne izložbe važnim segmentom pokazala se primjena formata MARC 21, koji je zbog standardiziranosti prikaza, korisničke dostupnosti bibliografskog zapisa na mrežnom katalogu te mogućnosti povezivanja zapisa uz digitalni repozitorij i virtualnu izložbu, pokazao prednosti u odnosu na druge baze za inventarizaciju koje nisu mrežno dostupne. Tim prednostima treba dodati i povezanost sustava Indigo s Alephom, koja omogućuje prenošenje podataka i formiranje digitalne zbirke.

Uz navedene prednosti tog procesa, važno je istaknuti i prepreku koja se javila tijekom izrade virtualne izložbe, a to je nemogućnost preuzimanja metapodataka iz sustava Aleph ili Indigo (Digitalne zbirke Nacionalne i sveučilišne knjižnice u Zagrebu) u WordPress, što otvara pitanje mogućnosti integracije podataka od knjižničnog kataloga i repozitorija do virtualne izložbe, kao i unos podataka iz drugih sustava. Rješenje koje bi omogućilo takvu cjelovitu integraciju podataka 
osiguralo bi i cjelovito predstavljanje opusa jednog autora i interpretacije njegovih radova, zbog čega je u slučaju ove virtualne izložbe riječ o povezivanju digitalnih podataka koje se temelji na prednosti platforme WordPress u odnosu na navedene sustave zbog mogućnosti okupljanja i predstavljanja građe iz drugih izvora i bolje vizualizacije podataka.

Iako ova virtualna izložba svojim procesom izrade i rezultatom svjedoči o potrebi softverske dorade u smjeru cjelovitog integriranja podataka, kao prva izložba izrađena za likovnu građu, koja je donijela novitete i u izradi virtualnih izložbi Nacionalne i sveučilišne knjižnice u Zagrebu, svojim problematičnim točkama može u budućnosti biti primjer za izradu novih rješenja, a kao inovativan način prezentiranja takve vrste građe može biti primjer i daljnji poticaj za uključivanje u proces digitalne prezentacije kulturne baštine.

\section{LITERATURA}

Conrad von Hötzendorf, Hugo. // Hrvatski biografski leksikon. [citirano: 2018-05-10]. Dostupno na: http://hbl.lzmk.hr/clanak.aspx?id=3651.

Crteži Huga Conrada von Hötzendorfa. [citirano:2018-06-06]. Dostupno na: http://virtualna.nsk.hr/hotzendorf/.

Digitalne zbirke Nacionalne i sveučilišne knjižnice u Zagrebu. [citirano: 2018-06-06]. Dostupno na: https://digitalna.nsk.hr/pb/.

Dumitrescu, G.; C. Lepadatu.; C. Ciurea, Creating virtual exhibitions for educational and cultural development. // Informatica Economică 18, 1(2014), str. 107. [citirano: 2018-05-02]. Dostupno na: http://revistaie.ase.ro/content/69/09\%20-\%20Dumitrescu,\%20Lepadatu,\%20Ciurea.pdf.

Handbook on virtual exhibitions and virtual performances: version 1.0. Ministro per i beni e le attivita culturali; INDICAT, 2012. [citirano: 2018-03-15]. Dostupno na: http://www.digitalmeetsculture.net/wp-content/uploads/2013/01/Handbook_on_ Virtual_Exhibitions_and_Virtual_Performaces.pdf.

ISBD: međunarodni standardni bibliografski opis / preporučila Skupina za pregled ISBD-a; odobrio stalni odbor IFLA-ine Sekcije za katalogizaciju; [s engleskog prevela i predgovor napisala Ana Barbarić]. Objedinjeno izd. Zagreb : Hrvatsko knjižničarsko društvo, 2014.

Miletić Drder, M.; L. Jurić Vukadin; M. Vujić; M. Vučković Pepeonik. Geografska imena [Elektronička građa] : upute za izradu i klasificiranje predmetnih preglednih zapisa u formatu MARC 21. Zagreb: Nacionalna i sveučilišna knjižnica u Zagrebu, 2012. [citirano: 2018-05-10]. Dostupno na: http://www.nsk.hr/wp-content/uploads/2012/04/geografske-predmetne-odrednice.pdf. 
M++: priručnik za rad. Link 2, 2004. [citirano:2018-06-06]. Dostupno na: http://mdc.hr/ files/pdf/koordinacija-mreze-muzeja/prirucnik5.pdf.

Švajcer, O. Hötzendorf. Zagreb: Centar za povijesne znanosti, Odjel za povijest umjetnosti, 1982.

Vlašić Jurić, V. Crteži Huga Conrada von Hötzendorfa u Grafičkoj zbirci Nacionalne i sveučilišne knjižnice u Zagrebu: katalog izložbe., Zagreb: Nacionalna i sveučilišna knjižnica u Zagrebu, 2017.

Vlašić Jurić, V; T. Ilić Olujić. Važnost odrednice za vrstu i fizičko obilježje pri sadržajnoj obradi i analizi likovnih djela : na primjeru likovne građe iz Grafičke zbirke NSK u Zagrebu. // Vjesnik bibliotekara Hrvatske 57, 1-3(2014), 378-390. Dostupno i na: https://www.hkdrustvo.hr/vjesnik-bibliotekara-hrvatske/index.php/vbh/article/ view/128/123 [citirano: 2018-05-10]. 